\title{
Bone turnover assessment: a good surrogate marker?
}

\author{
Avaliação da remodelação óssea: um bom marcador substituto?
}

Patrícia Dreyer ${ }^{1}$, José Gilberto H. Vieira' ${ }^{1}$

\section{SUMMARY}

To asses fracture risk, bone mineral density (BMD) measured by dual-energy X-ray absorptiometry (DXA) is the most commonly used tool. The search for clinical risk factors is also advised and can provide a 10 -year fracture probability (FRAX model). Another important determinant of bone strength is bone remodeling. High bone remodeling rates have been associated with a higher fracture risk and bone turnover markers (BTM) may offer dynamic information about skeletal status independent of BMD. The efficacy of antiresorptive agents in fracture prevention goes beyond what can be predicted by BMD especially in the beginning of the treatment. Inhibition of bone remodeling itself is certainly an important mechanism by which antiresorptive agents can rapidly reduce fracture risk. Thus, it seems quite logical to use BTM in patients with bone disease. It can also become a valuable surrogate marker in fracture prediction. However, BTM's pre-analytical and analytical variability should always be considered. Arq Bras Endocrinol Metab. 2010;54(2):99-105

\section{Keywords}

Bone turnover; biochemical markers; osteoporosis; fracture

\section{SUMÁRIO}

O método mais utilizado para avaliação do risco de fraturas é a densitometria óssea pela técnica de DXA (absorciometria por raios-X duo-energética). A pesquisa de condições clínicas de risco também é recomendada e fornece uma estimativa da probabilidade de fratura em 10 anos (modelo FRAX). Outro fator importante é o grau de remodelação óssea. Um aumento da taxa de remodelação tem sido associado a um maior risco de fraturas e aumento dos marcadores ósseos. A medida desses marcadores fornece informação adicional independente da densitometria. A eficiência das medicações antirreabsortivas na prevenção de fraturas não é explicada apenas pelo aumento da densidade óssea. A menor remodelação óssea é um mecanismo que pode explicar a redução da taxa de fraturas principalmente no início do tratamento. A utilização desses marcadores nas doenças ósseas e na predição de fraturas torna-se lógica. No entanto, para interpretá-los corretamente sua variação pré-analítica e analítica deve ser considerada. Arq Bras Endocrinol Metab. 2010;54(2):99-105

\section{Descritores}

Remodelação óssea; marcadores ósseos; osteoporose; fratura

\section{INTRODUCTION}

$\mathrm{T}$ en years have passed since we first published in the Brazilian Archives of Endocrinology and Metabolism a review article on bone turnover markers (BTM) and their practical application (1). In the meantime, evolution on this subject has been tremendous with better understanding of bone physiology, development of new biochemical markers and new assays along with
1 Disciplina de Endocrinologia, Unidade de Metabolismo Ósseo e Mineral, Escola Paulista de Medicina, Universidade Federal de São Paulo (Unifesp/ EPM), São Paulo, SP, Brasil

\author{
Correspondence to: \\ Patrícia Dreyer \\ Fleury - Centro de Medicina \\ Diagnóstica \\ Rua Cincinato Braga, 232 \\ 01333-010 - São Paulo, SP, Brasil \\ patricia.dreyer@fleury.com.br
}

Received on Dec/22/2009

Accepted on Feb/9/2010 cumulative research on how BTM can be used in the assessment of bone disease and its treatment. Among bone disorders, osteoporosis is far more common and corresponds to a major health issue mainly because it leads to increased susceptibility to fractures.

The rationale of all osteoporosis therapies concentrates in one primary endpoint which is fracture prevention. The main issue regarding drug efficacy is how one 
can evaluate fracture rate reduction. To do so, there is need of an observational period (usually years) and monitoring of a high number of patients in a specific population (regarding age and sex differences) $(2,3)$. For this reason, there is a necessity for a surrogate marker, i.e., a tool intended to predict a clinical endpoint (fracture rate). The importance of surrogate markers in osteoporosis was recently discussed by Bouxsein and Delmas (4). They recommend that an ideal surrogate marker must have specific characteristics: biological plausibility (i.e., relation between biomarkers and pathogenetic mechanisms leading to increased skeletal fragility); association between biomarker and fracture in the target population; biomarkers can change consistently in response to therapy, preferably in a predictable and dose-dependent fashion that agrees with the known mechanism of action of the therapeutic intervention; changes in biomarkers with treatment explain a substantial proportion of the antifracture efficacy.

The most widely used tool in osteoporosis diagnosis and follow-up is bone mineral density (BMD) measured by dual-energy X-ray absorptiometry (DXA) which has a strong correlation with fracture risk $(5,6)$. BMD measurement can certainly provide useful information but holds some restrictions: the differences in bone density detected by DXA are gradual and a period of 1 or 2 years is usually necessary to identify significant changes after therapy has started. In addition, adherence to medication is a well-known problem in osteoporosis patients as in any other chronic asymptomatic disease (7). To wait at least one year to verify BMD changes with treatment is not the most effective way to incite patient adherence. Furthermore, the absence of BMD increase does not imply absence of therapeutic response. Indeed, BMD represents an important but not exclusive dimension of bone strength. For example, a women aged 75 years is four to seven times more likely to experience a fracture than a woman aged 45 years with the same BMD (8).

In attempt to better estimate fracture risk the World Health Organization (WHO) developed the FRAX tool which calculates a 10 year probability of osteoporotic fracture based on clinical risk factors such as body mass index, fracture history, parental fracture history, presence of secondary causes of osteoporosis, use of glucocorticoids as well as smoking status and alcohol consumption with or without BMD measurements (9). Unfortunately, in Brazil we are unable to use the FRAX tool because specific epidemiologic data is lacking.
An important determinant of bone strength that is not assessed by BMD or clinical risk factors is bone turnover. High bone turnover is associated with more severe forms of osteoporosis and an increased fracture risk. Hence, BTM can reflect the dynamic nature of bone formation and resorption in a process that is usually coupled. Inhibition of bone remodeling itself is certainly another mechanism by which antiresorptive agents can rapidly reduce fracture risk before BMD changes (10). Additionally, BTM can independently provide a tool for monitoring response to therapy after only 2-3 months $(11,12)$. Therefore, bone turnover assessment emerges as a valuable surrogate marker in osteoporosis. Their clinical use, advantages and limitations will be discussed below.

\section{BONE TURNOVER MARKERS AND REMODELING BIOLOGY}

Bone is a dynamic tissue that is continually renewed by a process called bone turnover. A variety of circulating and local factors act on osteoblasts (bone forming cells) to initiate remodeling. The osteoblasts signal for differentiation and maturation of osteoclast precursors (bone resorbing cells) which carry out dissolution of bone matrix constituents leading to the development of a resorptive cavity. After a short period of 2-3 weeks resorbing osteoclasts undergo apoptosis and osteoblasts move into the resorption cavity laying down a cement line (osteoid), synthesizing new matrix which will undergo further mineralization. The bone formation process takes several months and as new bone is made some osteoblasts are buried in the matrix and become osteocytes. This special type of cell can transduce mechanical signals necessary for adaptative modeling and remodeling in face of changing loads (13).

Depending upon their origin, BTM are classified as formation or resorption markers. If bone physiology is preserved, formation and resorption are coupled phases and BTM changes in parallel. In many bone diseases, this coupling is lost and bone resorption prevails over bone formation leading to increased bone turnover. The major condition in which this imbalance occurs is in post-menopausal osteoporosis when resorption markers tend to be higher than formation markers (14). On the other hand, conditions like osteopetrosis display an opposite state in which formation markers are much more elevated than resorption markers. The selection of which BMT to use should be based on the 
physiopathological process occurring in each bone disorder or in the mechanism of action of a specific drug, when used to monitor treatment.

\section{BONE FORMATION MARKERS}

\section{Procollagen I extension peptides}

Type I collagen is synthesized by osteoblasts as the precursor molecule (procollagen) with extension peptides in the carboxy $(\mathrm{C})$ and amino $(\mathrm{N})$ ends. These extensions are cleaved by proteases during collagen extracellular metabolism giving rise to $\mathrm{N}$-terminal (PINP) and C-terminal (PICP) propeptides of type I collagen (Figure 1). They go into the circulation as a trimeric form which is rapidly converted in its monomeric form and represents a marker of type I collagen synthesis (15). Different assays can measure both monomeric and trimeric forms. PINP measurement has practical advantages of a low diurnal variability, its circulating levels are not significantly influenced by food intake (patient does not need to be fasting) and it is primarily metabolized by the liver with clearance unaffected by renal dysfunction $(16,17)$.

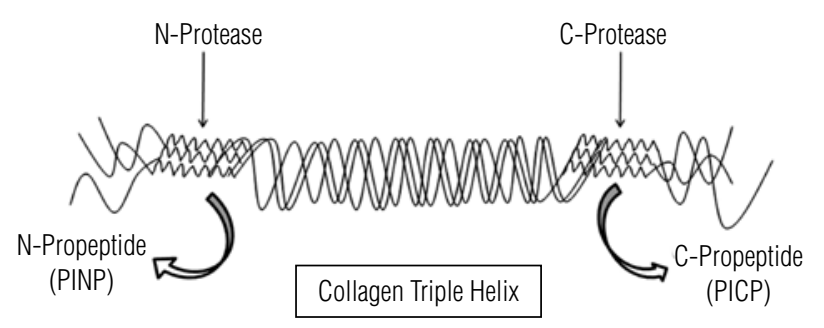

Figure 1. The catabolism of procollagen extension peptides by proteases during collagen formation leads to PICP and PINP production.

\section{Bone-specific alkaline phosphatase}

There are several isoforms of alkaline phosphatase originating from many tissues, mainly liver and bone in a proportion of $50 \%$ each in normal subjects. The automation of specific immunoassays for bone-specific alkaline phosphatase (BSAP) has improved in recent years but there is a significant cross-reactivity of $15 \%$ with the liver form which can be clinically relevant in patients with liver disease (18). BSAP is produced by osteoblasts during the synthesis of the collagen matrix and increases local concentration if inorganic phosphate destroys pyrophosphate which inhibits mineral crystallizations and acts as a calcium-binding protein. It has a half-life of 1-2 days making it less sensitive to circadian variation, and it is not influenced by renal dysfunction (19).

\section{Osteocalcin}

Osteocalcin is the most abundant non-collagen protein found in bone. Its structure is monomeric and contains 49 aminoacid and three-gamma-carboxyglutamic acid residues which are responsible for the calcium-binding properties of the molecule. During osteoid synthesis, osteocalcin is released by osteoblasts and it is involved primarily in bone mineralization. A small fraction of osteocalcin is released into the circulation and has a circadian rhythm peaking at $4 \mathrm{a} . \mathrm{m}$. It is also cleared by the kidney and its levels are affected by renal dysfunction. Osteocalcin has a short half-life of less than an hour and is quickly degraded so that intact molecules and fragments coexist in circulation (20). There are different assays to measure the intact peptide and/or its fragments making comparison between them difficult.

\section{BONE RESORPTION MARKERS}

\section{Telopeptides of type I collagen}

These specific peptides are degradation products of the non-helical region of type I collagen in the aminoterminal region (NTX) and the carboxy-terminal region (CTX) produced by osteoclasts during bone resorption (Figure 2). NTX and CTX can be measured in either serum or urine. The serum levels are influenced by circadian rhythm and food intake therefore samples must be collected at the same time of the day (in the morning) and in fasting conditions (21). The 24-hour urine collection has the advantage of overcoming circadian changes and is less sensitive to dietary interferences, although patients may find it difficult to collect urine properly. Increasingly the automated CTX serum assay has become more available and is replacing urinary NTX because of its simplicity and robust performance. Reference intervals should be age and sex-specific.

\section{Pyridinium cross-links}

The cross-links (aldehyde links between lysine or hydroxylysine residues) are formed between collagen molecules (Figure 2) and are released into circulation when collagen is catabolized. They follow a circadian 
rhythm and are higher early in the morning and are less influenced by diet. There are two types of crosslinks currently available in serum and urine: Pyridinoline (which is less specific and can be derived from cartilage, tendons and blood vessels) and Deoxypyridinoline (more specific and found in bone and dentin). Nowadays immunoassays are preferred instead of highperformance liquid chromatography (HPLC) used in the past $(22,23)$.

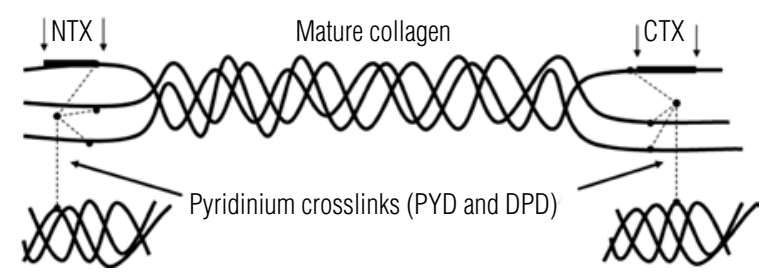

Figure 2. The catabolism of mature collagen by osteoblasts produces telopeptides and pyridinium crosslinks.

\section{Acid phosphatase}

Osteoclasts produce an acid phosphatase isoenzyme which is not inhibited by tartrate called type 5 tartrate resistant acid phosphatase band $5 \mathrm{~b}$ (TRAP $5 \mathrm{~b}$ ). This enzyme is present in the osteoclast's ruffled border membrane and in the resorptive space. Increased TRAP $5 \mathrm{~b}$ levels have been described in high bone turnover states like Paget's disease and bone metastasis. Recently, due to assay evolution, TRAP $5 \mathrm{~b}$ is becoming one of the BTM used for prediction of high bone turnover with a significant correlation with BMD loss (24).

\section{RECOMMENDATIONS IN BTM ANALYSIS AND INTERPRETATION}

For practical reasons, serum samples are more used than urine samples when measuring BTM. Fasting is recommended and blood samples should be obtained in early morning. Bone resorption peaks in the second half of the night (between 3 and 7 a.m.) and has its nadir in the late afternoon (25). Bone formation has less circadian variability. The time between sample collection, centrifugation and storage shoud be no longer than 4 hours. All samples must be transported in refrigerated conditions to assure their stability. Osteocalcin is very sensitive to temperature and should be handled in an ice bath. If stored at $-20^{\circ} \mathrm{C}$, BTMs are stable for several months. Exercise should be avoided preceding sample collection because it can increase bone turnover (26). Age and sex strongly influence BTM. Values are significantly higher in children and post-menopausal women when compared to adults. Reference ranges adjusted for age and sex must be used for better interpretation but this information is not always available $(27,28)$. Coexistent health conditions such as bed rest and immobility, bone metastases, acromegaly and thyrotoxicosis (all of them increasing bone resorption) may change bone turnover $(29,30)$. A recently sustained fracture alters bone turnover. Bone formation and resorption markers increase as early as a minimum of 4 months after the fracture, reflecting bone healing (31).

Drugs can modify bone turnover, predominantly in case of corticosteroid use. They promptly inhibit bone formation with a fall in osteocalcin, PINP and BSAP. The use of corticosteroids (prednisone $5 \mathrm{mg}$ or equivalent) can already decrease bone formation. Higher doses (more than $7.5 \mathrm{mg}$ prednisone daily or equivalent exceeding 3 months) not only decreases bone formation and but also increases bone resorption $(32,33)$. The use of thiazolinediones can alter bone turnover mainly decreasing bone formation by induced activation of PPAR in mesenchymatous cells promoting their differentiation into adipocytes in preference to osteoblasts (34).

Another important issue to be considered is BTM interpretation is the Least Significant Change (LSC) of each marker. LSC calculation includes pre-analytical and analytical variations by using standard statistic methods providing a range of values that a given test must exceed to conclude that a true biological effect is happening in opposition to the measurement error (35). Recent guidelines have suggested that a decrease of at least $30 \%$ for serum markers and $50 \%-60 \%$ of urinary markers need to be observed to suggest that a biological event has occurred (36). For instance, patients treated with alendronate that exhibit a decrease greater that $30 \%$ in BSAP had significant lower risk of spine or hip fracture compared with those with BSAP changes below $30 \%$ from baseline (it is important to remember that bone resorption and formation are coupled) (37). With risedronate therapy, improvement in the rates of vertebral fractures were noted when changes greater than $60 \%$ from baseline in urinary CTX and changes greater than $40 \%$ in urinary NTX were observed (38). In teriparatide trials changes greater than $40 \%$ in PINP should occur before a biological effect may be inferred, 
although some evidence suggests that this limit should be at least $20 \%(39,40)$. Thus, the need of specific reference intervals in different ages and establishment of LSC could be obstacles in the use of BTM in clinical practice. There are growing efforts to define these intervals for each BTM considering the within-subject and between-subject variation so that serial measurements may provide clinical insights into bone metabolism changes.

\section{CLINICAL VALUE OF BTM ASSESSMENT}

The association between higher bone turnover rate and the risk of fracture has been confirmed in several prospective and cohort studies. Higher levels of resorption markers are associated with a two-fold increase of vertebral and non-vertebral fractures compared to women with normal BTM levels in a population older than 65 years of age $(41,42)$ and younger than 65 years $(43)$. Interestingly, osteopenic women with high BTM levels are at risk of fracture similar to that of osteoporotic women. But osteopenic women with normal BTM have a low fracture risk comparable to post-menopausal women with normal BMD (44). Additionally, increased urinary levels of deoxypyridinoline were associated with higher risk of hip fractures in elderly women with normal BMD from the EPIDOS cohort (45). Since a large proportion of women who suffer fragility fracture have a BMD above the defined osteoporotic threshold (T-score of $-2,5$ or less) (46), BTM provide another way of assessing fracture risk independent of and complementary to BMD measurements.

Another potential utility of BTM is using bone turnover as a guide to drug selection. For example, women with a high turnover rate should receive antiresorptive treatment and those with low remodeling rates could benefit from an anabolic agent. Some studies have found a higher fracture reduction with bisphosphonates in women with high resorption markers $(47,48)$. However, there is not enough evidence or practical guidelines to recommend this conduct in clinical practice.

Currently, the chief clinical application of BMT measurements is monitoring response to therapy. Changes in BTM during treatment depend on the marker type evaluated, cellular mechanism of a drug's action, its potency and route of administration. Bisphosphonate administered orally decreases bone resorption in 3 weeks with a nadir after 3-6 months and stable values thereafter. There is also a decrease in bone formation markers with a nadir after 6-12 months. Intravenous bisphosphonates and subcutaneous denosumab induces a more rapidly dose dependent decrease in bone resorption. The higher the dose the lower are the resorption markers and higher the increase in BMD (49-50). During anabolic treatment with teriparatide, for example, an increase in bone formation is followed by an increase in bone resorption. After 1 month, PINP increases about 60\%-70\% above baseline and continues to rise for 3-6 months and then decreases. A rise in CTX is also observed at a lesser extent (5l). Strontium Ranelate has modest impact in BTM and slightly increases BSAP and slightly decreases serum CTX during initial use, then both plateau throughout treatment (52). The changes in BTM levels after withdraw of osteoporotic medication are related to posterior changes in BMD and a probable decrease in anti-fracture efficacy (53). This could be one of the guiding points in the decision to restart therapy or to extend drug suspension without the need to wait for a decrease in BMD. Finally, as with any relatively asymptomatic disease, adherence to treatment is poor in osteoporosis (nearly $50 \%$ at 6 months for oral medications) and anti-fracture efficacy is linked to continuous treatment (54). It is possible that BMT measurements improve adherence to osteoporosis treatment since their change occurs much earlier than it can be detected by BMD, but this observation has not been demonstrated conclusively in clinical trials.

\section{CONCLUSION}

Bone turnover assessment is a valuable tool in management of osteoporosis and other bone diseases. Potential clinical uses of BTM include prediction of bone loss and fracture risk, monitoring drug action and adherence to osteoporosis therapy. Limitations imposed by pre-analytical and analytical interferences should always be considered. Nevertheless, BTM are increasingly becoming good surrogate markers and their association with BMD measurement can provide a better view of bone status.

Disclosure: both of the authors are part of Fleury Group, São Paulo, Brazil.

\section{REFERENCES}

1. Vieira JG. Considerações sobre os marcadores bioquímicos do metabolismo ósseo e sua utilidade prática. Arq Bras Endocrinol Metab. 1999;43(6):415-22. 
2. Committee for medicinal products for medical use. Guideline on the evaluation of medical products in the treatment of primary osteoporosis. European Medicines Agency, London, UK, 2006.

3. Food and Drug Administration. Guidelines for preclinical and clinical evaluation of agents used in the prevention of treatment of postmenopausal osteoporosis. Food and Drug Administration, Washington, DC, USA, 1994.

4. Bouxsein ML, Delmas PD. Considerations for development of surrogate endpoints for antifracture efficacy of new treatments in osteoporosis: a perspective. J Bone Miner Res. 2008;23(8):1155-67.

5. Cummins SR, Bates D, Black DM. Clinical use of bone densitometry: clinical applications. JAMA. 2002;288(15):1898-900.

6. Johnell O, Kanis JA, Oden A, Johansson H, De Laet C, Delmas P, et al. Predictive value of BMD for hip and other fractures. J Bone Miner Res. 2005;20(7):1185-94.

7. Caro JJ, Ishak KJ, Huybrechts KF, Raggio G, Naujoks C. The impact of compliance with osteoporosis therapy on fracture rates in actual practice. Osteopos Int. 2004;15(12):1003-8.

8. Burr DB. Introduction - Bone turnover and fracture risk. J Musculoskelet Neuronal Interact. 2003;3(4):408-9.

9. Kanis JA, Johnell O, Oden A, Johansson H, McCloskey E. FRAX and the assessment of fracture probability in men and women from the UK. Osteoporos Int. 2008;19(4):385-97.

10. Garnero P, Sornay-Rendu E, Chapuy MC, Delmas PD. Increased bone turnover in late postmenopausal women is a major determinant of osteoporosis. J Bone Miner Res. 1996;11(3):337-49.

11. Burnett-Bowie SM, Saag K, Sebba A, de Papp AE, Chen E, Rosenberg $\mathrm{E}$, et al. Prediction of changes in bone mineral density in postmenopausal women treated with once-weekly bisphosphonates. J Clin Endocrinol Metab. 2009;94(4):1097-03.

12. Bonnick SL, Shulman L. Monitoring osteoporosis therapy: bone mineral density, bone turnover markers, or both? Am J Med. 2006;119(4 Suppl 1):S25-31.

13. Martin TJ, Seeman E. Bone remodelling: its local regulation and the emergence of bone fragility. Best Pract Res Clin Endocrinol Metab. 2008;22(5):701-22.

14. Kushida K, Takahashi M, InoueT. Comparison of markers for bone formation and resorption in premenopausal and postmenopausal subjects, and osteoporosis patients. J Clin Endocrinol Metab. 1995;80(8):2447-50.

15. Risteli J, Risteli L. Products of bone collagen metabolism. Dynamics of bone and cartilage metabolism. Seibel MJ, Robins SP, Bilezikian JP, editors. San Diego, Academic press; 1999. p. 275-87.

16. Clowes JA, Hannon RA, Yap TS, Hoyle NR, Blumsohn A, Eastell R. Effect of feeding on bone turnover markers and its impact on biological variability of measurements. Bone. 2002;30(6):886-90.

17. Melkko J, HellevikT, Risteli L, Risteli J, Smedsrod B. Clearance of $\mathrm{NH} 2$-terminal propeptides of types I and III procollagen is a physiological function of the scavenger receptor in liver endothelial cells. J Exp Med. 1994;179(2):405-12.

18. Garnero P, Delmas PD. Assessment of the serum levels of alkaline phosphatase with a new immunoradiometric assay in patients with metabolic bone disease. J Clin Endocrinol Metab. 1993;77(4):1046-53.

19. Eastell R, Hannon RA. Biomarkers of bone health and osteoporosis risk. Proc Nutr Soc. 2008;67(2):157-62.

20. Garnero P, Grimaux M, Demiaux B, Preaudat C, Seguin P, Delmas PD. Measurement of serum osteocalcin with a humanspecific two-site immunoradiometric assay. J Bone Miner Res. 1992;7(12):1389-98.

21. Schlemmer $A$, Hassager $C$. Acute fasting diminishes the circadian rhythm of biochemical markers of bone resorption. Eur J Endocrinol. 1999;140(4):332-7.

22. Eyre DR, Paz MA, Gallop PM. Cross-linking in collagen and elastin. Annu Rev Biochem. 1984:53:717-48.
23. Kamel S, Brazier M, Néri V, Picard C, Samson L, Desmet G, et al. Multiple molecular forms of pyridinolines cross-links excreted in human urine evaluated by chromatographic and immunoassay methods. J Bone Miner Res. 1995;10(9):1385-92.

24. Ivaska KK, Lenora J, Gerdhem P, Akesson K, Väänänen HK, Obrant KJ. Serial assessment of serum bone metabolism markers identifies women with the highest rate of bone loss and osteoporosis risk. J Clin Endocrinol Metab. 2008;93(7):2622-32.

25. Qvist $P$, Christgau S, Pedersen BJ, Schlemmer A, Christiansen C. Circadian variation in the serum concentration of $\mathrm{C}$-terminal telopeptide of type I collagen (serum CTx): effects of gender, age, menopausal status, posture, daylight, serum cortisol, and fasting. Bone. 2002;31(1):57-61.

26. Marcus R. Exercise: moving in the right direction. J Bone Miner Res. 1998;13(12):1793-6.

27. Rauchenzauner $M$, Schmid $A$, Heinz-Erian $P$, Kapelari $K$, Falkensammer G, Griesmacher A, et al. Sex- and age-specific reference curves for serum markers of bone turnover in healthy children from 2 months to 18 years. J Clin Endocrinol Metab. 2007;92(2):443-9.

28. Glover SJ, Gall M, Schoenborn-Kellenberger O, Wagener M, Delmas PD, Eastell R, et al. Establishing a reference interval for bone turnover markers in 637 healthy, young, premenopausal women from the United Kingdom, France, Belgium, and United States. J Bone Miner Res. 2009;24(3):389-97.

29. Uebelhart D, Bernard J, Hartmann DJ, Moro L, Roth M, Uebelhart $B$, et al. Modifications of bone and connective tissue after orthostatic bedrest. Osteopos Int. 2000;11(1):59-67.

30. Amarante ECJ, Kasamatsu TS, Kunii IS, Vieira JG. Avaliação da excreção urinária de piridinolina e deoxipiridinolina em pacientes com hipertiroidismo e sua correlação com níveis de hormônios tiroidianos e densidade mineral óssea. Arq Bras Endocrinol Metab. 1996;40:258-63.

31. Ivaska KK, Gerdhem P, Akesson K, Garnero P, Obrant KJ. Effect of fracture on bone turnover markers: a longitudinal study comparing marker levels before and after injury in 113 elderly women. $J$ Bone Miner Res. 2007;22(8):1155-64.

32. Lems WF, Van Veen GJ, Gerrits MI, Jacobs JW, Houben HH, Van Rijn $\mathrm{HJ}$, et al. Effect of low dose prednisone (with calcium and calcitriol supplementation) on calcium and bone metabolism in healthy volunteers. Br J Rheumat. 1998;37(1):27-33.

33. Ton FN, Gunawardene SC, Lee H, Neer RM. Effects of lowdose prednisone on bone metabolism. J Bone Miner Res. 2005;20(3):464-70.

34. Grey A, Bolland M, Gamble G, Wattie D, Horne A, Davidson J, et al. The peroxisome proliferator-activated receptor- $\gamma$ agonist rosiglitazone decreases bone formation and bone mineral density in healthy postmenopausal women: a randomized, controlled trial. J Clin Endocrinol Metab. 2007;92(4):1305-10.

35. Smellie WS. What is a significant difference between sequential laboratory results? J Clin Pathol. 2008;6(4)1:419-25.

36. Bergmann P, Body JJ, Boonen S, Boutsen Y, Devogelaer JP, Goemaere $S$, et al. Evidence-based guidelines for the use of biochemical markers of bone turnover in the selection and monitoring of bisphosphonate treatment in osteoporosis: a consensus document of the Belgian Bone Club. Int J Clin Pract. 2009;63(1):19-26.

37. Bauer DC, Black DM, Garnero P, Hochberg M, Ott S, Orloff J, et al. Change in bone turnover and hip, non-spine, and vertebral fracture in alendronate-treated women: the fracture intervention trial. J Bone Miner Res. 2004;19(8):1250-8.

38. Eastell R, Barton I, Hannon RA, Chines A, Garnero P, Delmas PD. Relationship of early changes in bone resorption to the reduction in fracture risk with risedronate. J Bone Miner Res. 2003;18(6):1051-6.

39. Gallagher JC, Rosen CJ, Chen P, Misurski DA, Marcus R. Response rate of bone mineral density to teriparatide in postmenopausal women with osteoporosis. Bone. 2006;39(6):1268-75. 
40. Eastell R, Krege JH, Chen P, Glass EV, Reginster JY. Development of an algorithm for using PINP to monitor treatment of patients with teriparatide. Curr Med Res Opin. 2006;22(1):61-6.

41. Garnero P. Biomarkers for osteoporosis management: utility in diagnosis, fracture risk prediction and therapy monitoring. Mol Diagn Ther. 2008;12(3):157-70.

42. Garnero P, Sornay-Rendu E, Chapuy MC, Delmas PD. Increased bone turnover in late postmenopausal women is a major determinant of osteoporosis. J Bone Miner Res. 1996;11(3):337-49.

43. Garnero P, Sornay-Rendu E, Claustrat B, Delmas PD. Biochemical markers of bone turnover, endogenous hormones and the risk of fractures in postmenopausal women: the OFELY study. J Bone Miner Res. 2000;15(8):1526-36.

44. Sornay-Rendu E, Munoz F, Garnero P, Duboeuf F, Delmas PD. Identification of osteopenic women at high risk of fracture: the OFELY study. J Bone Miner Res. 2005;20(10):1813-9.

45. Robbins JA, Schott AM, Garnero P, Delmas PD, Hans D, Meunier PJ. Risk factors for hip fracture in women with high BMD: EPIDOS study. Osteoporos Int. 2005;16(12):149-54.

46. Siris ES, Chen YT, Abbott TA, Barrett-Connor E, Miller PD, Wehren LE, et al. Bone mineral density thresholds for pharmacological intervention to prevent fractures. Arch Intern Med. 2004;164(10):1108-12.

47. Gonnelli S, Cepollaro C, Pondrelli C, Martini S, Montagnani A, Monaco $\mathrm{R}$, et al. Bone turnover and the response to alendronate treatment in postmenopausal osteoporosis. Calcif Tissue Int. 1999;65(5):359-64.
48. Bauer DC, Garnero P, Hochberg MC, Santora A, Delmas P, Ewing $\mathrm{SK}$, et al. Pretreatment levels of bone turnover and the antifracture efficacy of alendronate: the fracture intervention trial. J Bone Miner Res. 2006;21(12):291-99.

49. McClung MR, Lewiecki EM, Cohen SB, Bolognese MA, Woodson $\mathrm{GC}$, Moffett AH, et al. Denosumab in postmenopausal women with low bone mineral density. N Engl J Med. 2006;354(8):821-31.

50. Reid IR, Brown JP, Burckhardt P, Horowitz Z, Richardson P,Trechsel U, et al. Intravenous zoledronic acid in postmenopausal women with low bone mineral density. N Engl J Med. 2002;346(9):653-61.

51. Glover SJ, Eastell R, McCloskey EV, Rogers A, Garnero P, Lowery J, et al Rapid and robust response of biochemical markers of bone formation to teriparatide therapy. Bone. 2009;45(6):1053-8.

52. Meunier PJ, Roux C, Seeman E, Ortolani S, Badurski JE, Spector $T D$, et al. The effects of strontium ranelate on the risk of vertebral fracture in women with postmenopausal osteoporosis. N Engl J Med. 2004;350(5):459-68.

53. Greenspan SL, Emkey RD, Bone HG, Weiss SR, Bell NH, Downs $\mathrm{RW}$, et al. Significant differential effects of alendronate, estrogen, or combination therapy on the rate of bone loss after discontinuation of treatment of postmenopausal osteoporosis. A randomized, double-blind, placebo-controlled trial. Ann Intern Med. 2002;137(11):875-83.

54. Ivaska KK, Gerdhem P, Väänänen HK, Akesson K, Obrant KJ. Bone turnover markers and prediction of fracture: a prospective followup study of 1040 elderly women for a mean of nine years. J Bone Miner Res. Epub 2009 Dec 6. 